\title{
The Relationship between Real Output (Real GDP) and Unemployment Rate: An Analysis of Okun's Law for Eurozone
}

Utku ALTUNÖZ (http://orcid.org/0000-0002-0232-3108), Department of Business Administration, Sinop University,Turkey; e-mail: utku_al@sinop.edu.tr

\section{Reel Çıktı (Reel GSYİH) ve İşsizlik Oranı İlişkisi: Euro Bölgesi İçin Okun Yasası Analizi}

\begin{abstract}
In this study, the relationship between economic growth and unemployment in the euro area (eurozone) is investigated in the light of Okun's Law by using annual panel data set covering the period 2000-2012. Besides panel error correction and panel integration methods are used to test the link between unemployment and growth rate, unemployment hysteresis was examined by using several non-stationary panel unit root techniques for in all countries included to the study. Findings of this study propose that the Okun's Law is valid. However, the cointegration coefficient is lower than the Okun's coefficient calculated for the United States and other studies which was done for developed countries. The US is included in the analysis as it has the strongest economy in the world. In addition, since growth and unemployment are more volatile in developing countries, they are included in the analysis in order to compare with developed countries.
\end{abstract}

Keywords $\quad$ : Okun's Law, Unemployment, Economic Growth, Panel

Cointegration, Eurozone.

JEL Classification Codes : $\quad$ R11, R15.

\section{$\ddot{\mathbf{O} z}$}

Bu çalışmada Euro bölgesi için ekonomik büyüme ile işsizlik arasındaki ilişi Okun Yasası doğrultusunda 2000-2012 yılları için yıllık panel veri analizi ile test edilecektir. Bu amaçla işsizlik histerisi panel hata düzeltme ve panel bütünleşme ve çeşitli panel birim kök testleri yardımıyla testleri kullanılmıştır. Bu çalışmanın bulguları, Okun Yasasının geçerli olduğunu önermektedir. Bununla birlikte, eş bütünleşme katsayısı, Okun'un ABD ve diğer ülkeler için yapılan diğer çalışmalar için hesaplanan katsayısından düşüktür. $\mathrm{ABD}$ dünyadaki en güçlü ekonomiye sahip olduğu için analize dâhil edilmiştir. Ayrıca, büyüme ve işsizlik gelişmekte olan ülkelerde daha değişken olduğundan, gelişmiş ülkelerle karşılaştırmak amacıyla analize dâhil edilmiştir.

Anahtar Sözcükler $\quad$ : Okun Yasası, İşsizlik, Ekonomik Büyüme, Panel Eşbütünleşme, Euro Alan1. 


\section{Introduction}

Arthur Okun the study of the relationship between real growth rate and unemployment is known as Okun's Law in the economic literature. According to Okun, real GDP growth by $1 \%$ above the trend value of $2.25 \%$, reduces the unemployment rate by $0.5 \%$. In the relevant study it was stated that the values are for the US economy and around $1 \%$ of annual population growth rate. Okun (1962) made use of three different models to prove this claim. These models are called first differences, trial exploits, and appropriate tendency and flexibility. In the first difference method, changes in the unemployment rate (Y) every 3 months in percentage and 3 months in GNP (X) were associated. It was estimated from 55 observations between 1947:2Q - 1960:4Q. The result is the equation (1) below:

$$
Y=0.30-0.30 X
$$

As can be understood from the equation, an increase of $1 \%$ in GDP reduces the unemployment level by 0.3 points. It comes into play when selecting and testing certain exponential values of the potential adversary in the test deficit section. The corresponding regression equation is established with the arrow. Equation of unemployment as equation (2) below;

$$
U=a+b
$$

The results of models made by Okun were presented to the unified economic committee in 1961. The presented model is like equation (3).

$$
U=3.72 \_0.36
$$

Equation (3) means that unemployment is $3.72 \%$ in the absence of a current deficit.

Last section was named as the appropriate tendency and flexibility by Okun. While the first part is based on GNP and the change in unemployment, the second part is based on the level values of these variables on the assumption that the growth trend is constant unemployment rate in the second method (Muratoğlu, 2011:26).

One of the most urgent problems in Europe is unemployment that rose from $4 \%$ in the 1960 s to $10 \%$ in the 1990 s. However, despite the social and economic consequences of high unemployment rates, some additional problems remain unresolved such as reason that which one causes the existence of unemployment rates, does the size of unemployment follow an autonomous route independent from other macroeconomic variables such as inflation? (Christopoulos, 2004: 2). The answers are relevant to the empirical examination of the relationship between unemployment and output. Mentioned variables, that is, unemployment and output are affected to by the business cycle, we expect a long-term relationship between these variables. This context, high output growth rates will lead to a decrease in unemployment. But we find ourselves: when output expansion is limited, unemployment moves in the opposite direction. Theoretical proposals on output and unemployment are called the "Okun's Law" (Okun, 1962). On an empirical basis, the 
"Okun's Law" allows the implementation of a more appropriate economic policy to reduce unemployment.

Most of the empirical literature examining the validity of Okun's Law is presupposed to be a symmetrical relationship between unemployment and real output growth. Okun's (1962) original work states that the economy experienced a $1 \%$ unit increase in unemployment for every $3 \%$ unit decrease gross domestic product from its long-run level. Similarly, a 3\% unit increase in gross domestic product from its long-run level is associated with a $1 \%$ unit decrease in unemployment. It is important to keep in mind that changes in output are related to changes in the number of changes in labor force participation, to ensure that the relationship between changes in production and change in unemployment is not individual. Changes in per capita working hours and labor productivity. Okun estimated that $3 \%$ unit increase in gross domestic product from its long-run level corresponded to a $0.5 \%$ point increase in the labor force participation rate, a $0.5 \%$ unit increase in the hours worked per employee, and a $1 \%$ unit increase in labor productivity, leaving the remaining $1 \%$ unit to be the change in the unemployment rate. During the Okun's period, the relationship between changes in unemployment and changes in output has been predicted to be about 2 to 1 rather than the 3 to 1 that Okun originally proposed. In addition, economists have pointed out that the relationship between changes in unemployment and changes in output is not perfect, and that the Okun's Law will be considered as a rule in general, rather than an absolute management principle.

\section{Real Output (Real GDP) and Unemployment in Eurozone}

At the beginning of 2000 , more than 20.5 million people were unemployed in the EU-28, accounting for $9.2 \%$ of the total. At that time the trend of unemployment was down. In the second quarter of 2001, the unemployment rate decreased to 19.6 million and the unemployment rate to $8.7 \%$ kforce.

The increase in unemployment followed a long time.

At the end of 2004, the number of job seekers reached 21.2 billion, while the unemployment rate was $9.2 \%$. At the beginning of 2005, a period of unemployment started to take shape until the first quarter of 2008. In this period, after the economic crisis, the EU28 unemployment rate exceeded 16.2 million. The unemployment rate between the second quarter of 2008 and the middle of 2010 has increased by more than 6.7 million and it has increased to the highest value recorded since the beginning of the year in 2000 by $9.7 \%$. The decline in unemployment in the following three quarters was a deceptive sign of a steady recovery in the end of the crisis and labor market conditions in the EU-28. As a matter of fact, until the second quarter of 2011 and the second quarter of 2013, unemployment has risen steadily, reaching a record high of 26.5 million, reaching a record high of $11 \%$. Since then, the rate has fallen to $8.2 \%$ in 2016. As can be seen in Chart 1 , the eurozone unemployment rate rose to $7.2 \%$ in 2008 , when the euro entered the market until spring 2008. With the onset of financial turmoil and the sharp economic slowdown associated with 
it, unemployment has begun. Markedly increased. As of 2009, the eurozone unemployment rate was $9.6 \%$ - the highest rate recorded in ten years.

\section{Chart: 1}

\section{Unemployment Rate of Eurozone (2008-2018)}

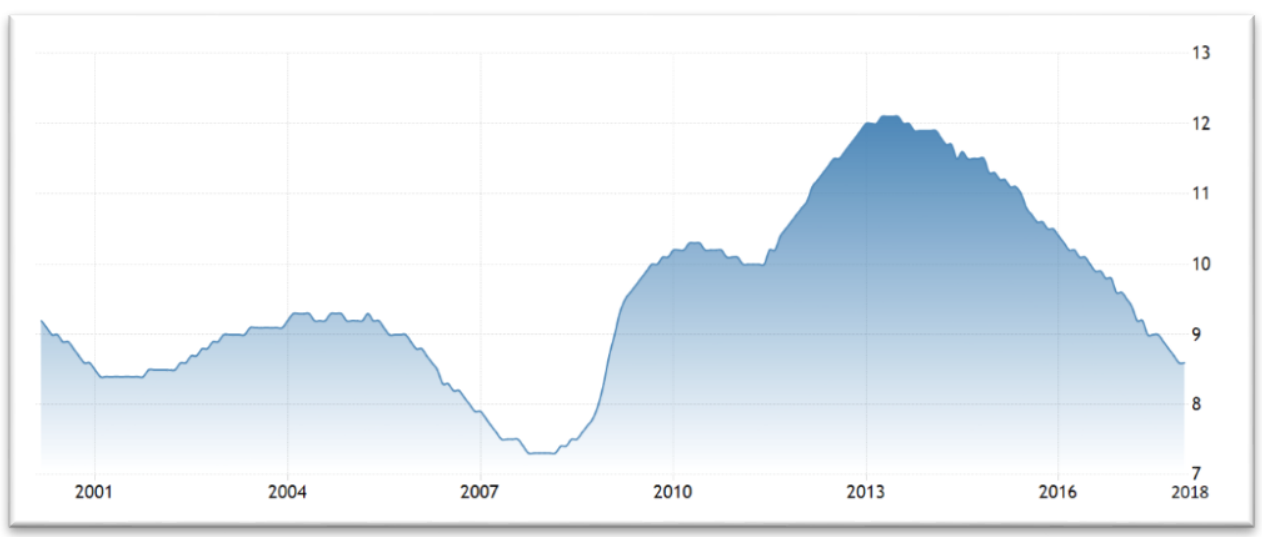

Source: Eurostat.

As of September of 2017, unemployment in the Eurozone has hit its lowest level since January 2009, new data have revealed. The proportion of workers who were unemployed in the Eurozone fell to 8.9 in September 2017, according to the European Union data bank Eurostat. This unemployment rate is better than the 9-percentage point recorded in August and a percentage point improvement in September 2016. According to Eurostat, 17.000 million men and women in 28 territories in the EU region and 14.000 million in the euro area (EA-19) were unemployed in January 2011. According to December 2017, the number of unemployed fell by 19.000 in the EU-28 and 10.000 in the euro area. As of January 2017, the unemployment rate fell by 1.867 million in the EU-28 and 1.429 million in the euro area. While real output (real domestic product) is widely used to measure the overall size of an economy. And, it is commonly used to compare living standards derived from indicators such as per capita gross domestic product those adjusted for differences in dollar, dollar, or price levels. As to be seen in Chart 2 below, the global economic and financial crisis caused a serious stagnation in Japan, The United States and European Union in 2009. This was followed by a recovery in 2010. The crisis was already apparent in 2008, when the rate of increase declined significantly. GDP in EU-28 and this was followed by a $4.4 \%$ decline in real GDP in 2009. The recovery in the EU-28 increased the volume index of GDP (based on chain-linked volumes) by $2.1 \%$ in 2010 and increased by $1.7 \%$ in 2011 . Subsequently, GDP contracted by $0.5 \%$ in real terms in 2012, reaching d rates in 2013 $(0.2 \%), 2014(1.6 \%)$ and $2015(2.2 \%) .-19)$, the rates of change up to 2010 in EU-28 are very similar. With growth in $2011(-1.5 \%)$ and in $2012(-0.9 \%)$ and in $2013(-0.3 \%)$. Real GDP growth in the euro area in 2014 and 2015 was weaker than in the EU-28. 
Chart: 2

\section{Gross Domestic Product of Eurozone (2008-2017)}

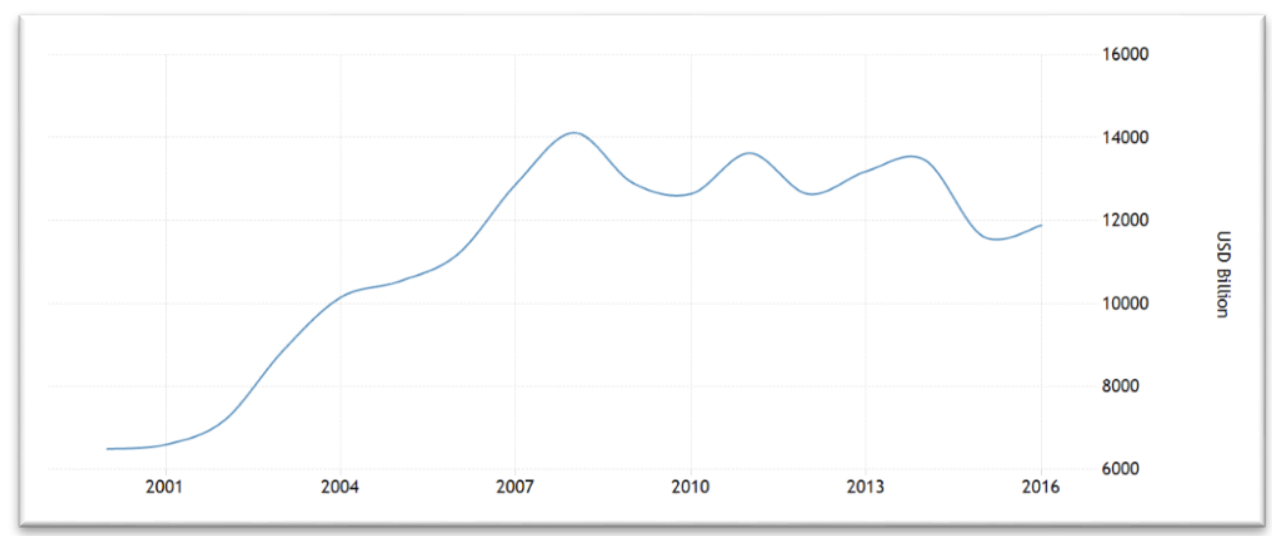

Source: Eurostat.

The Gross Domestic Product in the Euro Area increased by $2.7 \%$ year-on-year in the fourth quarter. In 2017, the GDP growth was $2.5 \%$, well below the previous $2.5 \%$ estimate and same level with 1.86\% in 2016. The GDP Annual Growth Rate in the Eurozone reached $1.68 \%$ from 1995 to 2017, the highest level ever. 
Chart: 3

Real GDP, Inflation, and Unemployment of Eurozone (2000-2016)

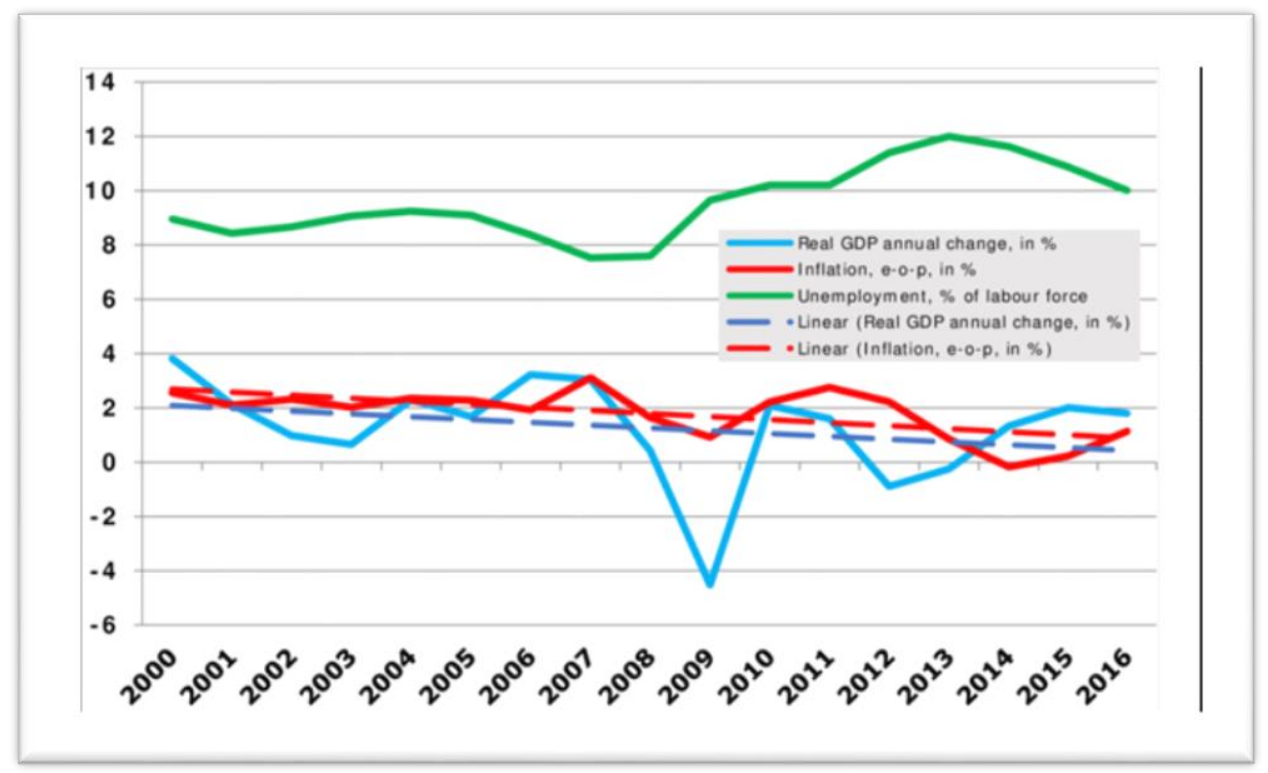

Source: IMF, October 2017.

Chart 3 shows together the real and linear GDP annual change in \%, inflation and linear inflation rate, unemployment rate of Euro area. According to Chart 2, tendency of the unemployment and real GDP don't support the coefficients claimed by Okun's Law. This situation can be observed in detail in Table 2 .

\section{Literature}

In this part of the study, domestic and foreign studies on the relationship between unemployment and economic growth will be examined.

Zagler (2003) used France, Germany, Italy, and England data for his study of Okun's Law with the vector error correction model. In the long run, he found that there is a cointegration relationship between economic growth and unemployment and that the relationship is positive. Christopoulos (2004) tested the validity of Okun's Law for Greece during the period 1971-1993. Applied on Greece economy, panel analysis showed that Okun's law can be confirmed for six out of the 13 regions. In the study that Holmes and Silverstone (2006) tested the Okun's Law for US economy on the Markov model, it couldn't reach the presence of a symmetrical relationship between growth and unemployment among variables. Malley and Molana (2008) have considered the dynamics of labor markets such as "effective wage", "unionization", "wage contracts", "unemployment insurance" in their 
studies examining the relationship between growth and unemployment for the 7 developed countries. As a result, they did not see that the relationship between the variables in Germany was more pronounced and stable. Pierdzioch et al. (2009) tested the Okun's law for G7 countries used data covering the period 1989-2007. Result of study supported the consistency between Okun's law which means the real output growth rate and professional economist's forecasts of changes in unemployment rate. Zonzilos (2000) investigated Okun's Law for Greece, over the period 1965-1999. His findings recommend that, if aggregate output increases by $1 \%$, then unemployment decreases by $0.28 \%$ under the ceteris paribus assumption. Based on these conclusions, the writer claims that the unemployment rate in Greece cannot be further reduced by adopting policies aimed at strengthening total demand. Villaverde ve Maza (2009) in a study that examines the relationship between growth and unemployment for the Spanish economy, they found that due to increase in unemployment, growth slows down. Demirgül (2010) aimed to contribute to the empirical literature about Okun's law. For this purpose, Demirgül used the periods between 1989 and 2007 with quarterly data for Turkey. The results show that there is stronger evidence of the ineffectiveness of the law of Okun, particularly during periods of abnormal productivity growth. Barıs et al. (2010), examined the validity of Okun's Law in Turkey and asymmetric relationship between unemployment and economic growth, with data 1988-2008 period using Markov-Switching approach. In the results of working; they reached the existence of the asymmetric structure for the relation between the variables depending on the expansion and contraction periods of the economy. In the study that Demirgil (2010) has been identified as Okun's relationship cannot be achieved over the periods 1987-2007 in Turkey when productivity increases. Lal et al. (2010), predicted the Okun's coefficient for the Asian countries by using Engle Granger (1987) co integration technique over the period 19802006. According to empirical evidences of study showed that Okun's law interpretation may not be applicable and the principle of non-accelerating inflation rate of unemployment (NAIRU) does not hold its validity in some Asian developing countries. Ball, Leigh, and Loungani (2012) examined the fits short-run unemployment movement of Okun's Law in in twenty advanced economies since 1980 and in the USA since 1948. At the end of the work, it is understood that Okun's law is stable and strong in many countries which have not changed greatly during the Great Recession. In the end of study, demonstrated that Okun's law is a stable and strong in the most countries, one that did not change substantially during the Great Recession. Bankole and Fatai (2013) predicted the coefficient of Okun and examined the validity of Okun's law for Nigeria Economy over the periods 1980-2008. For this purpose, Bankole and Fatai applied the Engle granger co-integration test and Fully Modified OLS. The empirical evidences demonstrated that there is positive coefficient in the Regression which means Okun's law interpretation is not applicable for Nigeria economy. Altunöz (2014) analyzed the validity of Okun's Law for Turkish economy covering the periods 2000-2014. In the end of study, Altunöz revealed that output effects unemployment while unemployment is not effective on output.

\section{Methodology}

According to Okun (1970) there should be two different type of model specification one of which is a gap model. The other one is the first difference model. The first difference 
model is described as, the relationship between the log of unemployment rate $\left(u n_{t}\right)$ and $\log$ of output $\left(g_{t}\right)$ is analyzed in the following function frame (Villaverdve \& Maza, 2009: 291):

$$
g_{t}-g_{t-1}=\alpha+\beta\left(u n_{t}-u n_{t-1}\right)+\mu_{t}
$$

In equation (5), $\alpha$ denotes the intercept and $\beta$ denotes the Okun's coefficient that measuring the change effect in the unemployment rate on real gross domestic product. Also, random walking term denotes by $\mu_{t}$. as below:

The second specification model called gap model is obtained by using equation (5)

$$
g_{t}-g_{t}^{*}=\alpha+\beta\left(u n_{t}-u n_{t}^{*}\right)+\varepsilon_{t}
$$

In equation (6), $g_{t}^{*}$ shows the natural rate of unemployment and the logarithm of potential gross domestic product (output). Except the two of mentioned, all variables in equation (6) are the same. The first term of the left-hand side in equation (6) denote the gap of employment which is equal the difference between observed and potential unemployment rates. However, the output gap which is equal to the difference between the observed and potential output (real gross domestic product) is captured by $g_{t}-g_{t}^{*}$. For this analysis, stationarity and cointegration conditions should be provided. In this paper, the first difference model out of two specifications for Okun's Law will be estimated.

On the other hand, the hypothesis of unemployment hysteresis shows that cyclical fluctuations will permanently affect the rate of unemployment due to labor market rigidities. In case of unemployment rate series has unit rate, we conclude that it carries a permanent effect in it.

On this paper hysteresis hypothesis which is support the unemployment rates are nonstationary, will be tested by focusing on ADF Panel unit root test as equation (7) below:

$$
\Delta u n_{i t}=\beta_{0 t}+\beta_{1 t} u n_{i t-1}+\beta_{2 t} t+\sum_{j=1}^{m} \beta_{3 t} \Delta u n_{i t-j}+\omega_{i t}
$$

By using different null and alternative hypothesis, several panel unit root tests constructed. For analyzing the stationary, two of them will be consider. These are LLC (Levin, et al., 2002), IPS (Im, et al., 2003). The alternative and null hypothesis of these unit root tests for equation (7) are as follow:

Table: 1

Null and Alternative Hypothesis of Applied Tests

\begin{tabular}{lcc}
\hline Unit Root Test & Null Hypothesis & Alternative Hypothesis \\
\hline LLC & $\beta_{1 i}=0$ & $\beta_{1 i}<0$ Tüm i ler için \\
IPS & $\beta_{1 i}=0$ & $\beta_{1 i}<0$ Bazı l ler için \\
\hline
\end{tabular}

In this analysis, Doğru's Study (2013) will be considered as a reference. cointegration analyses and vector error correction (VEC) techniques will be preferred in this study to determine the relationship between unemployment and real gross domestic product. 
Many recent studies indicate that a more contemporary approach to I(1) series are establishing a VEC model.

In vector error correction analysis, the first difference of each variables means as a function of its lagged values, the lagged values of the other explanatory variables, and cointegrating equation.

According to Doğru (2013) a simple vector error correction model with two variables using this paper $g_{t}$ and $u n_{t}$ besides lag length of 1 can be described as equation (8) below:

$$
\begin{aligned}
& \Delta g_{t}=\sum_{i=1}^{k} \alpha_{1 i} \Delta g_{t-1}+\sum_{i=1}^{k} \beta_{1 i} \Delta u n_{t-1}+\theta_{11}\left(\sim_{\epsilon}^{1}{ }_{t-1}\right)+\varepsilon_{i t} \\
& \Delta u n_{t}=\sum_{i=1}^{k} \alpha_{1 i} \Delta u n_{t-1}+\sum_{i=1}^{k} \beta_{2 i} \Delta u n_{t-1}+\theta_{21}\left(\sim_{\epsilon}^{1} 1_{t-1}\right)+\varepsilon_{2 t}
\end{aligned}
$$

In equation (8) and (9), $t$ represents the time, the first difference of the logarithm of the real output and the first difference of the logarithm of unemployment rate are respectively represented by $\Delta g_{t}$ and $\Delta u n_{t}$. $\varepsilon_{1 t-1}^{\tilde{1}}=g_{t-1}-y_{1}-\emptyset_{1} u n_{t}$ means the 1 year lagged disequilibrium residual. Estimated parameters are showed $\alpha, \varnothing, y, \phi$ and error correction term is showed with $\varepsilon$.

In this model, it is expected that $\emptyset_{1}$ should be negative which means an increase in unemployment related to decrease in real output.

In this part of the study, panel data analysis will be applied to the variables over the period 2001-2017. For this purpose, 17 countries which are use Euro as a common currency including the Netherlands, Spain, Slovakia, France, Slovenia, Portugal, Greece, Cyprus, Luxembourg, Finland, Germany, Ireland, Italy, Estonia, Austria, Malta and Belgium, will be included to the analysis. All data were obtained from IMF and World Bank.

Table: 2

\section{Result of Panel Unit Root Test Results}

\begin{tabular}{|c|c|c|c|c|c|}
\hline & & \multicolumn{2}{|c|}{ At Level } & \multicolumn{2}{c|}{ At First Difference } \\
\hline Variables & Test & LLC & IPS & LLC \\
\hline \multirow{2}{*}{$u n_{i t}$} & intercept & -0.772 & -0.312 & $-3288^{*}$ & $-8041^{*}$ \\
\cline { 2 - 5 } & intercept and trend & 1.213 & 0.312 & $-7212^{* *}$ \\
\hline \multirow{2}{*}{$g_{i t}$} & intercept & 1.615 & -4.311 & $8131^{*}$ & $-9354^{*}$ \\
\cline { 2 - 6 } & intercept and trend & 16.218 & 1.311 & $-6423^{* *}$ & $-12511^{*}$ \\
\hline
\end{tabular}

Note: *and ** show the significance at the $10 \%$ level and at the $5 \%$ level respectively.

Before the individual, all variables were applied the panel unit root test as seen in Table 2. According to panel unit root test, $H_{0}$ cannot be rejected at $0.01 \%, 0.05 \%$ and $0.10 \%$ significance in level for both unemployment and GDP panel data sets; nevertheless, it is rejected for the first differences. Result means that both series are non-stationary; they are I(1). Following the panel unit, individual intercept and trend and individual intercept and for pooled $u n$ and $g$ variables, Philips Peron (PP) and Augmented Dickey Fuller (ADF) unit root tests are implemented for each country as individually. Akaike information criterion (AIC) was considered for choosing the lag orders. 


\section{Table: 3}

\section{ADF and PP Individual Unit Root Test Results}

\begin{tabular}{|c|c|c|c|c|c|c|c|c|}
\hline \multirow{3}{*}{ Countries } & \multicolumn{4}{|c|}{ ADF Unit Root Test } & \multicolumn{4}{|c|}{ Philips Perron Unit Root Test } \\
\hline & \multicolumn{2}{|c|}{ Unemployment } & \multicolumn{2}{|c|}{ Real Gross Domestic Product } & \multicolumn{2}{|c|}{ Unemployment } & \multicolumn{2}{|c|}{ Real Gross Domestic Product } \\
\hline & At level & First Difference & At level & First Difference & At level & First Difference & At level & First Difference \\
\hline Netherlands & 1.211 & $0.890^{* *} *$ & 1.312 & 0.087 & 1.451 & 0.899 & 2.901 & 0.011 \\
\hline Spain & 1.720 & $0.097 * *$ & 1.233 & 0.081 & 1.980 & 0.798 & 2.108 & 0.790 \\
\hline Slovakia & 1.088 & $0.415 * *$ & 1.532 & 0.012 & 2.767 & 0.556 & 1.987 & 0.209 \\
\hline France & $0.981 * *$ & - & 1.089 & 0.413 & 3.019 & 0.376 & 1.078 & 0.014 \\
\hline Slovenia & $0.977 * *$ & - & $0.076 * *$ & - & $0.091^{* *} *$ & - & $0.780 * *$ & - \\
\hline Portugal & 1.111 & $0.989^{* *}$ & $0.776 * *$ & - & $0.057 * *$ & - & $0.060 * *$ & - \\
\hline Greece & 1.431 & $0.652 * *$ & 1.342 & 0.415 & 0.118 & 0.409 & 1.312 & 0.056 \\
\hline Cyprus & 1.113 & $0.246^{* *}$ & 1.665 & 0.331 & 2.109 & 0.899 & 1.111 & 0.866 \\
\hline Luxembourg & 1.561 & $0.902 * *$ & $0.071 * *$ & - & 2.190 & 0.312 & $0.067 * *$ & - \\
\hline Finland & 1.123 & 0.211 ** & 1.690 & 0.120 & 1.709 & 0.119 & 3.907 & 0.412 \\
\hline Germany & 1.087 & $0.245^{* *}$ & 1.809 & 0.149 & 1.590 & 0.856 & 1.120 & 0.221 \\
\hline Ireland & 1.111 & $0.145^{* *}$ & 1.765 & 0.217 & 1.760 & 0.908 & 2.901 & 0.512 \\
\hline Italy & 1.098 & $0.456^{* *}$ & 0.989 & 0.165 & 1.778 & 0.164 & 1.176 & 0.019 \\
\hline Estonia & 1.761 & 0.667 ** & $0.456 * *$ & - & $0.870^{* * *}$ & - & 1.412 & 0.710 \\
\hline Austria & 1.831 & $0.136^{* * *}$ & 1.443 & 0.133 & 1.809 & 0.243 & 1.117 & 0.030 \\
\hline Malta & 0.897 ** & - & 1.338 & 0.190 & 1.567 & 0.768 & 1.087 & 0.121 \\
\hline Belgium & 1.109 & $0.280^{* *}$ & 1.578 & 0.114 & 1.412 & 0.990 & 4.901 & 0.118 \\
\hline
\end{tabular}

Note: ** denotes the significance at the $5 \%$ level.

According to result of individual ADF unit root analysis seen in Table 3 the unemployment rate variable for all countries except France, Slovenia and Malta are stationary at first difference at least $10 \%$ significance level, while real output variable is stationary at first differences for all countries but at level for Slovenia, Portugal, Luxembourg and Estonia. Similarly, unemployment variable results of PP unit root test show that all variables except Slovenia, Portugal and Estonia are stationary at first difference for $10 \%$ significance level. According to gross domestic product variable result of PP unit root test, countries are stationary at first difference, but Slovenia, Portugal and Luxembourg are at level. One of the most important and known cointegration tests in econometric literature are these: McCoskey and Kao (1998), Kao (1999), Pedroni (1999), Larsson, Mark and Sul (2003), Westerlund and Edgerton (2005) and Gutierrez (2005).

In this study, Pedroni (1999) tests are used to determine the validity of long run relationship between unemployment rate and output in the pooled panel. Results is seen from Table 4 below:

Table: 4

Result of Panel Cointegration Test

\begin{tabular}{lcc}
\hline \multicolumn{1}{c}{ Within Dimension Tests } & Intercept & Intercept and Trend \\
\hline$v$ statistic of panel & 0.33 & -0.87 \\
rho(p) statistic of panel & 1.57 & $-0.09^{* *}$ \\
PP Statistic of panel & $-5.41^{* *}$ & $-9.145^{* *}$ \\
ADF Statistic of panel & $-2.67^{*}$ & $-5.89^{*}$ \\
\hline \multicolumn{1}{c}{ Between-dimension test } & \\
\hline rho (p) statistic of Group & 2.98 & 2.78 \\
PP statistic of Group & $3.12^{*}$ & $-7.46^{* *}$ \\
ADF Statistic of Group & $2.18^{*}$ & $-3.12^{* *}$ \\
\hline
\end{tabular}

Note: *and ** show the significance at the $10 \%$ level and at the $5 \%$ level respectively.

Result of the pooled Panel Cointegration Test except group p-test that is in order to determine of the validity of long run relationship between output and unemployment rate, provides the evidence on the steady-state equilibrium which means there is a causal 
interaction between unemployment and output. In the long-run for considered variables. Following the panel cointegration test, panel vector error correction model should be estimated to determine the causal interaction among variables. For this purpose, vector error correction (VEC) model will be estimated by considering equation (8) and equation (9).

Table: 5

VECM estimation result of Panel Long and Short Run Estimation

\begin{tabular}{|c|c|c|c|}
\hline \multicolumn{2}{|c|}{ Short Run Causality } & \multicolumn{2}{c|}{ Lon-run Causality } \\
\hline & $\Delta_{u n}$ & $\Delta_{\sigma}$ & ERM (Error Correction Term) \\
\hline$\Delta_{u n}$ & - & $0.841(0.561)$ & $-0.65^{*}$ \\
\hline$\Delta_{\sigma}$ & $0.238(0.066)$ & - & -4.12 \\
\hline \multicolumn{4}{|c|}{ Cointegration equation for panel: $g_{i t}=-0.718 u n_{i t}+\mu_{1 t}$} \\
\hline
\end{tabular}

Note: *and ** show the significance at the $10 \%$ level.

The coefficient of the error correction term shows the speed of adjustment to the longterm equilibrium. As can be seen in Table 5, the coefficient of the error correction term is 0.65 which means that previous period disequilibrium is corrected at a speed of $65 \%$ by system. Also, according to results in Table 5, in case of 1\% increase in unemployment expected reduction in real gross domestic product (realoutput) will reach to the $0.71 \%$ in the long run term. In addition, results in Table 5 shows that there is a short run causality from real gross domestic products to unemployment rate and it lasts to the long run. For long run term, unemployment is the cause of real gross domestic products but there are no relationships from unemployment to output. to make the results of the study more reliable, coefficient of Okun's Law will be estimated using fully modified ordinary least square and Dynamic Ordinary Least Square methods which were developed by Pedroni (2001). Coefficient of Okun's Law by fully modified ordinary least square and Dynamic Ordinary Least Square methods is presented Table 6 below:

Table: 6

Result of Panel Cointegration

\begin{tabular}{|l|c|c|}
\hline & $u_{n}$ & $g$ \\
\hline DOLS (Panel) & $-0.038^{* *}$ & $-0.09^{* *}$ \\
\hline FMOLS (Panel) & $-0.042^{* *}$ & -0.032 \\
\hline
\end{tabular}

Table 6 shows the coefficient of cointegration relationship for long run. According to result of Panel cointegration in Table 6, both Fully modified least square and dynamic ordinary least square, unemployment rate is negative related to real gross domestic product (real output). Results in Table 6 means that $1 \%$ decrease in the real output (real gross domestic product) causes to rise 0.03 unemployment rate besides, $1 \%$ increase in real gross domestic product causes to decrease unemployment rate $0.09 \%$.

According to Fully modified least square estimations, $1 \%$ decrease in real gross domestic product causes to rise unemployment rate $0.03 \%$ and $1 \%$ rise in unemployment rate causes to fall $0.042 \%$ in real gross domestic product. 
Altunöz, U. (2019), “The Relationship between Real Output (Real GDP) and Unemployment

Rate: An Analysis of Okun's Law for Eurozone", Sosyoekonomi, Vol. 27(40), 197-210.

\section{Conclusion}

In this study, validity of the Okun's Law, which means the relationship between real output (real gross domestic product and unemployment rate, was investigated for Eurozone economy. For this purpose, Netherlands, Spain, Slovakia, France, Slovenia, Portugal, Greece, Cyprus, Luxembourg, Finland, Germany, Ireland, Italy, Estonia, Austria, Malta and Belgium were included to the analysis. Before the econometric analysis, the theoretical infrastructure of Okun's Law has been mentioned. Immediately after, unemployment and real growth figures for the European Union have been analyzed comparatively. After the literature survey, Okun's Law was investigated for Eurozone by 2 different equations.

By using 2 different equations, panel integration methods and panel error correction were used to test the link between growth and unemployment rate. And, it was investigated the unemployment hysteresis using several non-stationary panel unit roots techniques for unemployment hysteresis in the whole euro zone. The results of the study suggest that there is evidence supporting the unemployment hysteria in many European countries and that panel cointegration tests support the relationship between the actual output and the unemployment rate in the long term. Also, according to results, in case of $1 \%$ increase in unemployment expected decrement in real output will reach to the $0.71 \%$ in the long run term which means that Okun's Law is equal to -0.71 pooled countries. In the other words, in case of $1 \%$ increase in unemployment expected decrement in real output will reach to the $0.71 \%$ in the long run term. Results of Coefficient of Okun's Law by fully modified ordinary least square and Dynamic Ordinary Least Square methods are as a parallel of VECM estimation result of Panel Long and Short Run Estimation that unemployment rate is negative related to real gross domestic product (real output). In this study, the long-term coefficient calculated from the panel data sets is lower than the coefficient obtained by Okun for America.

\section{References}

Altunöz, U. (2015), “Reel Büyüme ve İşsizlik Bağlamında Türkiye İçin Okun Yasası”, Kamu-İş Işs Hukuku ve İktisat Dergisi, 1(14), 47-67.

Bankole, A.S. \& B.O. Fatai (2013), “Empirical Test of Okun's Law in Nigeria”, International Journal of Economic Practices and Theories, 3(3), 227-231.

Barışık, S. \& E.İ. Çevik \& N. Kırcı-Çevik (2010), “Türkiye'de Okun Yasası, Asimetri İlişkisi ve İstihdam Yaratmayan Büyüme: Markov-Switching Yaklaşımı”, Maliye Dergisi, 159, 88102.

Breitung, J. (2001), "The local power of some unit root tests for panel data", in: B.H. Baltagi \& T.B. Fomby \& R.C. Hill (eds.), Non-stationary Panels, Panel Cointegration, and Dynamic Panels (Advances in Econometrics), Vol. 15, United Kingdom: Emerald Group Publishing Limited, 161-177.

Christopoulos, K.D. (2004), "The relationship between output and unemployment: Evidence from Greek regions", Papers in Regional Science, 83, 611-620.

Demirgil, H. (2010), Okun Yasasının Türkiye için Geçerliliğine dair Ampirik bir Çalışma”, Alanya Issletme Fakültesi Dergisi, 2(2), 139-151. 
Doğru, B. (2013), “The link between unemployment rate and real output in Eurozone: A panel error correction approach", $9^{\text {th }}$ International Strategic Management Conference, 99, 94-103.

EUROSTAT (online), Unemployment Statistics, <http://ec.europa.eu/eurostat/statisticsexplained/index.php/Unemployment_statistics>, 12.3.2018.

Holmes M.J. \& B. Silverstone (2006), “Okun's Law, Asymmetries and Jobless Recoveries in United States: A Markov-Switching Approach”, Economics Letters, 92(2), 293-299.

Im, K.S. \& M.H. Pesaran \& Y. Shin (2003), "Testing for Unit Roots in Heterogeneous Panels", (revise version of 1997's work), Journal of Econometrics, 115(1), 53-74.

Irfan, L. et al. (2010), “Test of Okun's Law in some Asian Countries: Cointegration Approach", European Journal of Scientific Research, 40(1), 73-80.

Kao, C. (1999), "Spurious Regression and Residual-Based Tests for Cointegration in Panel Data", Journal of Econometrics, 90(1), 1-44.

Larsson, R. \& L. Johan \& L. Mickael (2001), "Likelihood-Based Cointegration Tests in Heterogeneous Panels", Econometrics Journal, 4, 109-142.

Laurence, B. \& L. Daniel \& L. Prakash (2012), “Okun's Law: Fit at 50?”, Economics Working Paper Archive 606, The Johns Hopkins University, Department of Economics.

Levin, A. \& C.F. Lin \& C.S.J. Chu (2002), "Unit Root Test in Panel Data: Asymptotic and Finite Sample Propertiesî", Journal of Econometrics, 108, 1-24.

Luciano, G. (2005), “Tests for cointegration in panels with regime shifts”, Econometrics 0505007, University Library of Munich, Germany.

Malley, J. \& H. Molana (2008), “Output, Unemployment and Okun's Law: Some Evidence from G7”, Economics Letters, 101, 113-115.

Mc Coskey, S.K. \& K. Chihwa (1998), “A Residual-Based Test of the Null of Cointegration in Panel Data”, Econometric Reviews, 17(1), 57-84.

Muratoğlu, Y. (2011), “Ekonomik Büyüme ve İşsizlik Arasındaki Asimetrik İlişki ve Türkiye’de Okun Yasasının Sınanması", Yayımlanmamış Yüksek Lisans Tezi, Hitit Üniversitesi, Sosyal Bilimler Enstitüsü.

Okun, A.M. (1962), "Potential GNP: Its Measurement and Significance”, Cowles Foundation Paper $190,1-7$.

Pedroni, P. (1999), "Critical Values for Cointegration Tests in Heterogeneous Panels with Multiple Regressors", Oxford Bulletin of Economics and Statistics, 61, 653-670.

Pedroni, P. (2001), "Fully modified OLS for heterogeneous cointegrated panels", Advances in Econometrics, 93-130.

Pierdzioch, C. \& J-C Rulke \& G. Stadtmann (2009), "Do professional economists' forecasts reflect Okun's law? Some evidence for the G7 countries", Applied Economics, 43(11), 13651373.

Villaverde, J. \& A. Maza (2009), “The robustness of Okun's law in Spain, 1980-2004 Regional evidence", Journal of Policy Modeling, 31(2), 289-297.

Westerlund, J. \& E. David (2005), "Panel Cointegration Tests with Deterministic Trends and Structural Breaks", Lund University Working Papers, No. 42.

Zagler, M. (2003), “A Vector Error Correction Model of Economic Growth and Unemployment in Major European Countries and An Analysis of Okun's Law", Applied Econometrics and International Development, 3(3), 93-118. 
Altunöz, U. (2019), “The Relationship between Real Output (Real GDP) and Unemployment Rate: An Analysis of Okun's Law for Eurozone”, Sosyoekonomi, Vol. 27(40), 197-210.

Zonzilos, N.G. (2000), "The Phillips curve of the Greek economy and the time varying NAIRU”, Bank of Greece Economic Bulletin, Vol. 15. 